\title{
A bibliometric analysis of materials research in Indonesian journal using VOSviewer
}

\section{DOI:10.36909/jer.ASSEEE.16037}

\author{
Asep Bayu Dani Nandiyanto*, Dwi Fitria Al Husaeni
}

Fakultas Pendidikan Matematika dan Ilmu Pengetahuan Alam, Universitas Pendidikan Indonesia, Bandung, Indonesia.

*Email: nandiyanto@upi.edu; Corresponding Author.

\begin{abstract}
This study aims to analyze the scope of research on materials using a bibliometric review and data mapping process. Research data on materials were obtained from databases from selected journals in Indonesia. The search is done using a search engine that contains data on all related journal articles. The search process is based on a topic area with titles, keywords, and abstracts in the study material. The mapping process is done using VOSviewer. A total of 60 relevant articles were found. The results showed that the most studied study material was in the 2016-2021 range. Meanwhile, in the field of chemistry, the "acid" term is the most widely discussed material. Among all contributing countries, Indonesia is the largest country with 43 articles. Indonesia also has the most links with other countries, namely 8 links. Through VOSviewer we analyze how many articles have been published about the material and its relation to the topic area. This review can certainly provide a reference point for further research related to materials.
\end{abstract}

Key words: Bibliometric, Material, VOSviewer, Mapping. 


\section{INTRODUCTION}

Material is a substance or mixture of substances that make up an object. Materials can be pure or impure materials. Material can also be living or non-living matter. Materials can be classified according to their physical and chemical properties. Materials can also be based on their geological origin and biological function. Material is a substance or mixture that can be processed in various ways to affect its properties. This can be done by purification, formation, or introduction of other materials. In the industrial world, materials are inputs for a manufacturing process that will produce more complex and useful products or materials. Lots of research that discusses the material. The materials that have been researched are in the fields of chemistry and education. Research on materials in the chemical field that has been carried out includes research on waste materials (Permatasari et al., 2016), organic materials (Nandiyanto et al., 2016; Nandiyanto et al., 2018; Nandiyanto et al., 2019), corrosion materials (Asmara \& Kurniawan, 2018) and bio-battery materials (Maulida et al., 2021). There have been many studies on materials, but there is no research that discusses bibliometric analysis with the mapping process using VOSviewer. So that a comprehensive study is needed so that it can be used to help other researchers plan research related to materials. so that future researchers can research materials that are still rarely used.

This study aims to determine the development of research related to materials in Chemistry and Education research in terms of the distribution of bibliometric maps and research trends using VOSviewer software. VOSviewer software is used to map data (Al Husaeni \& Nandiyanto, 2022). Bibliometric analysis is considered effective in providing datasets that can be used to improve the quality of research (Nandiyanto et al., 2020). The bibliometric map has a distribution displayed consisting of the type of publication, the topic area studied, 
the country of origin of the researcher, the journal where the publication was published and the language used (Hamidah et al., 2020). However, in this study, the bibliometric used is a distribution consisting of the type of publication, the research topic area, the country of origin of the researcher, and the journal where the publication is published.

\section{MATERIALS AND METHOD}

All articles analyzed in this study were taken from a database of seven selected journals, namely the Indonesian Journal of Science and Technology (IJoST), ASEAN Journal of Science and Engineering (AJSE), ASEAN Journal of Science and Engineering Education (AJSEE), Indonesian Journal of Multidiciplinary Research. (IJoMR), Indonesian Journal of Community and Special Needs Education (IJCSNE), Indonesian Journal of Educational Research and Technology (IJERT), and Indonesian Journal of Teaching in Science (IJoTis). The research was conducted by collecting all publications in predetermined journals. After that, we proceed the data by creating a search engine to facilitate the analysis process. We enter the data article on the search engine that has been prepared.

We search the list of articles in the search engine that has been created. The search was carried out to filter articles with the keyword "Material" according to the title, keyword, and abstract (topic area) criteria. The articles used are articles published in the 2016-2021 range. The articles that have been collected and meet the requirements for analysis in this study are then entered into Microsoft Excel software and saved in comma separated values (*.csv) format. Furthermore, VOSviewer is used to visualize and analyze trends in the form of bibliometric maps. Then, we do data mapping of articles from database sources.

VOSviewer is used to create publication maps, country maps, or journal maps based on a network (co-citation) or to build keyword maps based on networks or relationships between 
existing items. At the time of making the bibliometric map, the keyword frequency is set as desired and the irrelevant or less relevant keywords are removed.

\section{RESULTS AND DISCUSSION}

Based on the search results from a database of several journals that have been determined (IJoST, AJSE, AJSEE, IJOMR, IJCSNE, IJERT, IJOTIS) obtained 60 data articles that meet the research criteria. The article data is divided into two categories, namely non-educational chemical materials and educational materials. Non-educational chemistry materials consist of 32 articles and 28 articles of Educational materials. Articles in 2016 were 3 articles, 2017 were 4 articles, 2018 were 4 articles, 2019 were 4 articles, 2020 were 6 articles and the rest are in 2021, which are 39 articles. Table 1 shows the data of the articles used in this study.

Table 1 Article Data with The Material in The Field of Chemistry

\begin{tabular}{|c|l|l|c|}
\hline No & \multicolumn{1}{|c|}{ Cite } & \multicolumn{1}{|c|}{ Topic } & Journal \\
\hline 1 & Permatasari et al. (2016) & $\begin{array}{l}\text { Analysis of silica sources from agricultural } \\
\text { waste (rice husk, rice straw, corn cobs, and } \\
\text { bagasse) and discusses the method of isolating } \\
\text { silica from agricultural waste and its } \\
\text { application as a catalyst. }\end{array}$ & IJoST \\
\hline 2 & Kurniawan et al. (2016) & $\begin{array}{l}\text { Overview of the high-temperature oxidation of } \\
\text { Fe-Cr steel under steam }\end{array}$ & IJoST \\
\hline 3 & Nandiyanto et al. (2016) & $\begin{array}{l}\text { This study investigates the } \\
\text { photodecomposition of organic matter during } \\
\text { partial solar motion and its correlation with the } \\
\text { amount of photocatalyst }\end{array}$ & IJoST \\
\hline 4 & Awan et al. (2017a) & $\begin{array}{l}\text { Effective utilization of pure acid oxidized } \\
\text { carbon nanofibers for strengthening of high- } \\
\text { performance cementitious materials. }\end{array}$ & IJoST \\
\hline 5 & Awan et al. (2017b) & $\begin{array}{l}\text { use of carbon nanofibers in cementitious } \\
\text { mortar materials with the microstructural } \\
\text { investigation }\end{array}$ & IJoST \\
\hline 6 & Bhullar \& Putra (2017) & $\begin{array}{l}\text { research on the design and modeling of the } \\
\text { production process of butyl cellosolve acetate } \\
\text { and EO-3 Phosphate ester }\end{array}$ & IJoST \\
\hline 7 & Bilad (2017) & $\begin{array}{l}\text { Module-scale simulation of the osmosis } \\
\text { module-part B using the modified spiral- } \\
\text { Wound method }\end{array}$ & IJoST \\
\hline
\end{tabular}




\begin{tabular}{|c|c|c|c|}
\hline No & Cite & Topic & Journal \\
\hline 8 & $\begin{array}{l}\text { Asmara \& Kurniawan } \\
\text { (2018) }\end{array}$ & $\begin{array}{l}\text { Literature review on prediction of corrosion } \\
\text { rate of carbon steel in oil and gas environment }\end{array}$ & IJoST \\
\hline 9 & Putra (2018) & $\begin{array}{l}\text { Literature review on the treatment of } \\
\text { lignocellulosic biomass in biorefinery }\end{array}$ & IJoST \\
\hline 10 & Nandiyanto et al. (2018) & $\begin{array}{l}\text { Analysis of ball-milling process in conditions } \\
\text { working volume, milling time, and material } \\
\text { load on the material properties, product yield, } \\
\text { and electricity consumption was investigated. }\end{array}$ & IJoST \\
\hline 11 & Kumalasari et al. (2018) & $\begin{array}{l}\text { Review the development phase change } \\
\text { materials incorporation of PCM in asphalt } \\
\text { pavement }\end{array}$ & IJoST \\
\hline 12 & Awan et al. (2019) & $\begin{array}{l}\text { Reinforcement of nanocarbon fiber in concrete } \\
\text { so that it can improve the flexural attributes, } \\
\text { impact resistance, and abrasion of concrete. }\end{array}$ & IJoST \\
\hline 13 & Nandiyanto et al. (2019) & $\begin{array}{l}\text { This research was conducted to find out how } \\
\text { to read and interpret the FTIR spectroscopy of } \\
\text { organic matter }\end{array}$ & IJoST \\
\hline 14 & Sumarji et al. (2019) & $\begin{array}{l}\text { The topic of this research about the effect of } \\
\text { particle dispersion on variations in mixing } \\
\text { speed }\end{array}$ & IJoST \\
\hline 15 & Nandiyanto (2019) & $\begin{array}{l}\text { development synthesis of Metal-organic } \\
\text { framework (MOF) materials }\end{array}$ & IJoST \\
\hline 16 & Priyand et al. (2020) & $\begin{array}{l}\text { Evaluating nanoparticles on zinc oxide }(\mathrm{ZnO}) \\
\text { materials }\end{array}$ & IJoST \\
\hline 17 & Saripudin et al. (2020) & $\begin{array}{l}\text { The development of the Information } \\
\text { Technology Open CourseWare (OCW) } \\
\text { movement and new opportunities in Asia to } \\
\text { support the education process }\end{array}$ & IJoST \\
\hline 18 & $\begin{array}{l}\text { Al Abbad \& Alakhras } \\
(2020)\end{array}$ & $\begin{array}{l}\text { The use of chitosan-iso-vanillin sorbent } \\
\text { material for removal of dye acid red } 1 .\end{array}$ & IJoST \\
\hline 19 & Budiman et al. (2020) & $\begin{array}{l}\text { Predicting the life of an inflatable rubber dam } \\
\text { taking into account deep hole damage }\end{array}$ & IJoST \\
\hline 20 & Kurniawan et al. (2020) & $\begin{array}{l}\text { Utilization of Stem Bark and Leaves of } \\
\text { Artocarpus Altilis Park materials as an Anti- } \\
\text { Mosquito Repellent }\end{array}$ & IJoST \\
\hline 21 & $\begin{array}{l}\text { Haristiani } \quad \& \quad \text { Rifa'i } \\
(2020) .\end{array}$ & $\begin{array}{l}\text { Combined chatbot and social media for } \\
\text { improved personal learning environment } \\
\text { (PLE) }\end{array}$ & IJoST \\
\hline 22 & Errich et al. (2021) & $\begin{array}{l}\text { removal of toxic heavy metals using } \\
\text { hydroxyapatite and hydroxyethylcellulose } \\
\text { material with Gum Arabic }\end{array}$ & IJoST \\
\hline 23 & Fitriyana et al. (2021) & $\begin{array}{l}\text { Investigation hypocholesterolemic activity of } \\
\text { Parkia roxburghii }\end{array}$ & IJoST \\
\hline
\end{tabular}




\begin{tabular}{|c|l|l|c|}
\hline No & \multicolumn{1}{|c|}{ Cite } & \multicolumn{1}{|c|}{ Topic } & Journal \\
\hline 24 & Castiblanco et al. (2021) & $\begin{array}{l}\text { The application of smart materials in Robotic } \\
\text { Hand Systems }\end{array}$ & IJoST \\
\hline 25 & Setiyo et al. (2021) & $\begin{array}{l}\text { Literature review and bibliometric analysis of } \\
\text { the latest reports on the advantages and } \\
\text { disadvantages of pure biodiesel materials on } \\
\text { engine performance }\end{array}$ & IJoST \\
\hline 26 & Syahputa et al. (2021) & $\begin{array}{l}\text { Development of the optimum combination of } \\
\text { the oxy-acetylene gas cutting process on 1045 } \\
\text { AISI steel material }\end{array}$ & AJSE \\
\hline 27 & $\begin{array}{l}\text { Swamy \& Zebenay } \\
\text { (2020). }\end{array}$ & $\begin{array}{l}\text { Design and Development of Landing Gear on } \\
\text { the elephant leg analogy }\end{array}$ & AJSE \\
\hline 28 & Elia et al. (2021) & $\begin{array}{l}\text { Techno-Economic Evaluation to determine the } \\
\text { feasibility of the Hyaluronic Acid } \\
\text { manufacturing process by Yellowfin Tuna } \\
\text { Eyeball Extraction }\end{array}$ & AJSE \\
\hline 29 & Obielodan et al. (2021) & $\begin{array}{l}\text { The Design and Construction Expert Appraisal } \\
\text { of 220 volts inverter at a frequency of 50H }\end{array}$ & AJSE \\
\hline 30 & Valensia et al. (2021) & $\begin{array}{l}\text { Creating alternative energy by utilizing } \\
\text { biomass materials }\end{array}$ & IJOMR \\
\hline 31 & $\begin{array}{l}\text { Amri \& Pagarsukma } \\
(2021)\end{array}$ & $\begin{array}{l}\text { Calculation of runway, taxiway, and apron } \\
\text { volume requirements for airplane development } \\
\text { planning IJOMR }\end{array}$ & IJOMR \\
\hline 32 & Mukti et al. (2021) & $\begin{array}{l}\text { finding solutions to get around the energy } \\
\text { crisis with vegetable waste material }\end{array}$ & IJOMR \\
\hline
\end{tabular}

The minimum number of relationships between terms in VOSviewer is set by 2 terms. after that, the data were analyzed using VOSviewer and the results were divided into 6 clusters:i) Cluster 1 is depicted in Red, ii) Cluster 2 is depicted in Green, iii) Cluster 3 is depicted in Blue, iv) Cluster 4 is depicted in Yellow, v) Cluster 5 is depicted in purple, and vi) Cluster 6 is depicted in Cyan. Each cluster shows the relationship between one term with another term. VOSviewer can display bibliometric mappings in three different visualizations; network visualization (Figure 1), overlay visualization (Figure 2), and density visualization (Figure 3). keywords are labeled with colored circles. The size of the circle is positively correlated with the occurrence of keywords in the title and abstract. Therefore, the size of letters and circles is determined by the frequency with which they occur. the more often the keyword appears, the larger the size of the letters and circles. 
Figure 1 shows the relationship between terms. Relationships in network visualization are depicted in a network or line that comes from one term to another (Al Husaeni \& Nandiyanto, 2021). Figure 1 shows the clusters in each of the researched topic areas. The study keyword is most closely related to other terms. The keywords of this study are in cluster 1 which consists of 53 items. Keyword study has 191 links.

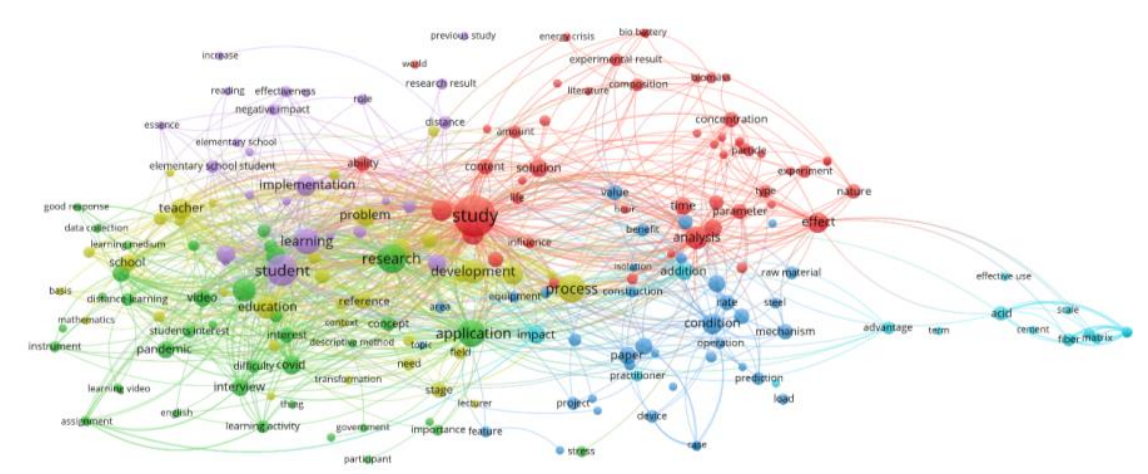

Figure 1 Network Visualization of Materials Keyword

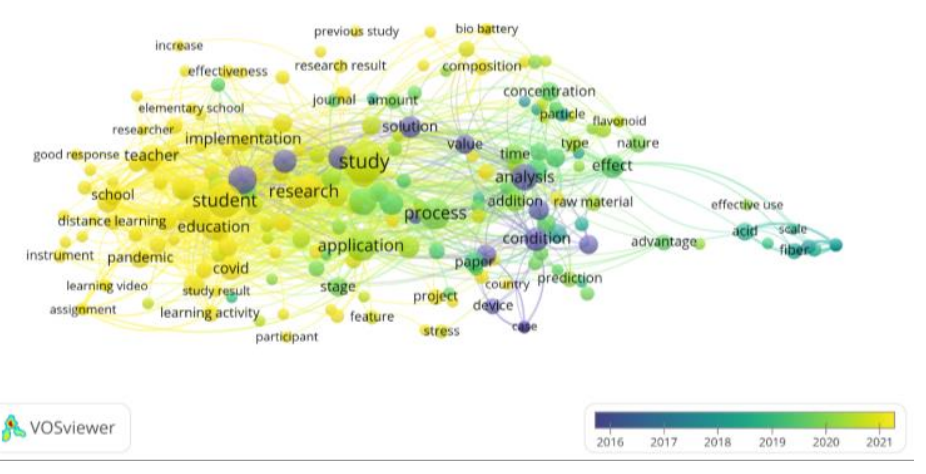

Figure 2 Overlay Visualization of Materials Keyword 


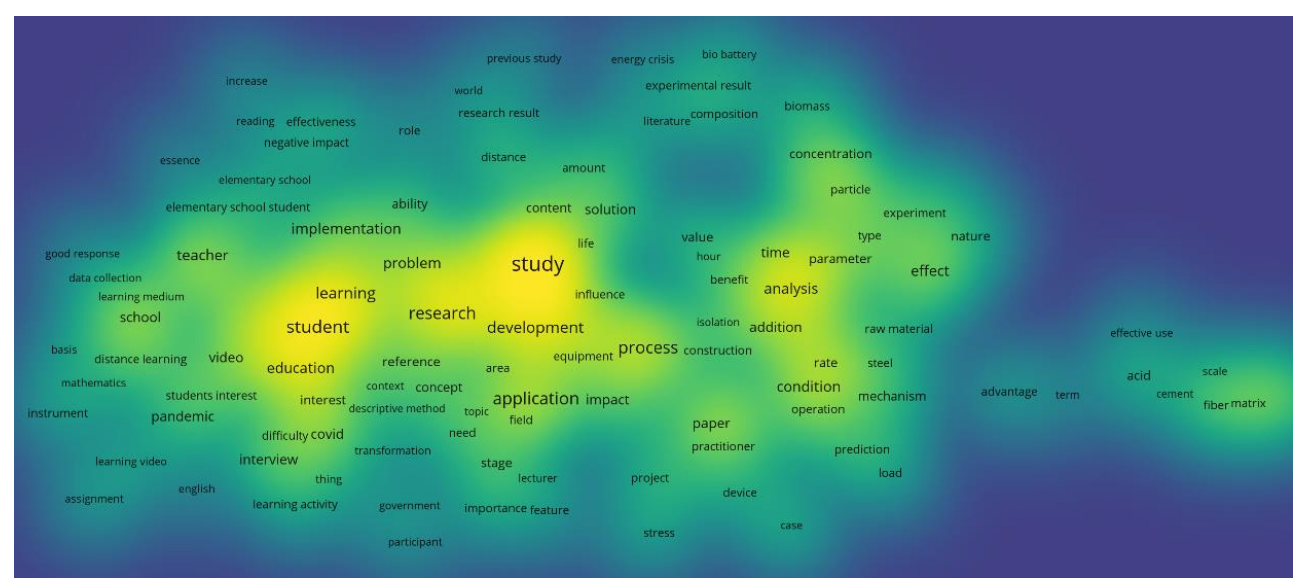

Figure 3 Density Visualization of Materials Keyword

Materials of Chemistry are also in the study keyword the most studied by people as shown in Figure 4. The material used as a product developer, acid material is the most studied. Figure 5 shows the relationship of material acid with other terms. Based on Figure 5, material acid is related to 17 other terms. The terms associated with the keyword acid include scale, fiber, addition, impact, effect, review, raw material, technology, production, application, structure, nature, study, work, process, information, and concentration. Overlay visualization shows the relationship between terms accompanied by the time the research is updated (Al Husaeni \& Nandiyanto, 2021). Figure 2 shows the trend from year to year related to research on materials. Research on materials based on Figure 2 is in the range of $2016-2021$.

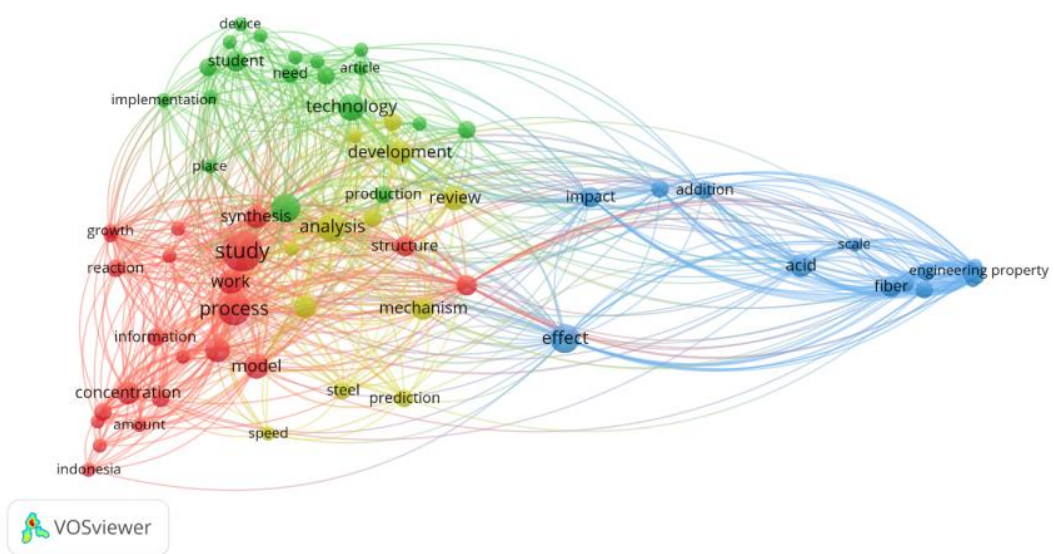

Figure 4 Network Visualization of Materials in Chemistry 


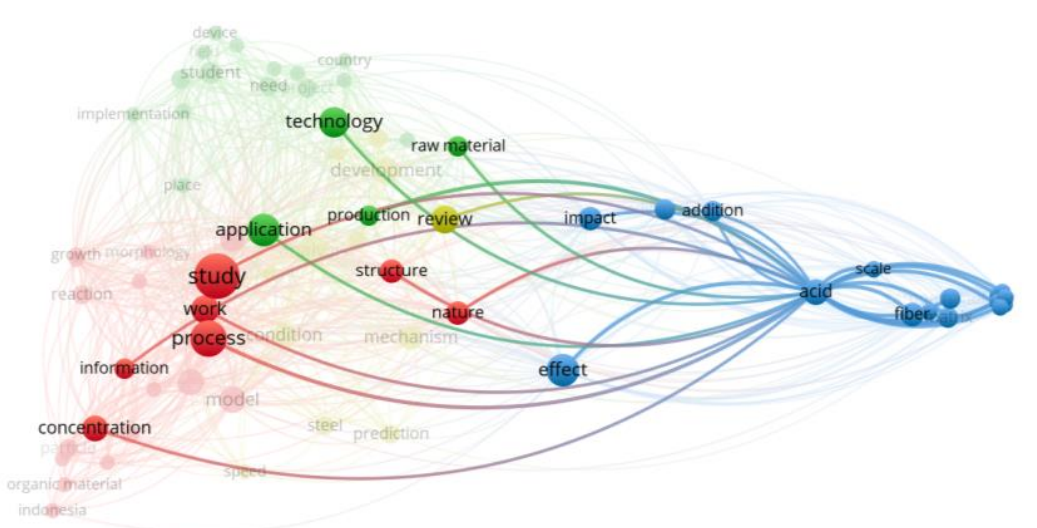

Figure 5 Network Visualization of Acid Material Relationship with Other Terms

The density visualization shown in Figure 3 means that the darker the yellow color and the larger the diameter of the circle, the denser the keywords, meaning that the more frequent the research on this subject is increasing. If the color fades, blends with the green background, the number of studies will decrease (Al Husaeni \& Nandiyanto, 2021). Figure 3 shows that materials in education have the most increasing number of researches, such as the keywords study, research, student, learning, application, and process.

The keywords that often appear are study, research, student, application, process, and learning. From this data, we can look for research on new materials. For example, research related to pure materials in the field of chemistry is still rarely done or published in a database of 7 journals that are used as references for data collection. In addition to the bibliometric analysis of the topic area, we analyze the country of the research study. Specifically for the study country, the bibliometric analysis is shown in Figure 6. In this study, 86 countries were involved. Indonesia contributed the largest research to publications published by 7 journals (IJoST, AJSE, AJSEE, IJOMR, IJCSNE, IJERT, and IJOTIS) which we are currently researching, namely 43 articles. Relations between countries are shown in Figure 7.

Figure 7 shows the relationship between countries when conducting research. From the 19 countries collected, there are only 11 countries that have connectedness, namely i) Cluster 1 
contains American Samoa, Pakistan, and United States, ii) Cluster 2 contains Indonesia, South Africa, and the United State, iii) Cluster 3 contains Brunei Darussalam and Qatar, iv) Cluster 4 contains Japan and Vietnam, and v) Cluster 5 is Malaysia.

From the 11 countries that are involved and interconnected, Indonesia has the most relationship links, which is about 8 links connected to the United States, Malaysia, South Africa, Japan, Vietnam, and Qatar. Malaysia has 1 link, which is connected to Indonesia, Japan has 2 links with Indonesia and Vietnam, South Africa has 1 link only with Indonesia, the United States is connected to Indonesia and Pakistan, Qatar is connected to Brunei Darussalam and Indonesia and vice versa Brunei Darussalam is connected to Qatar. and Indonesia. This shows that the articles related to the materials published in the journals that we study are international in scale and have connections between one country and another.

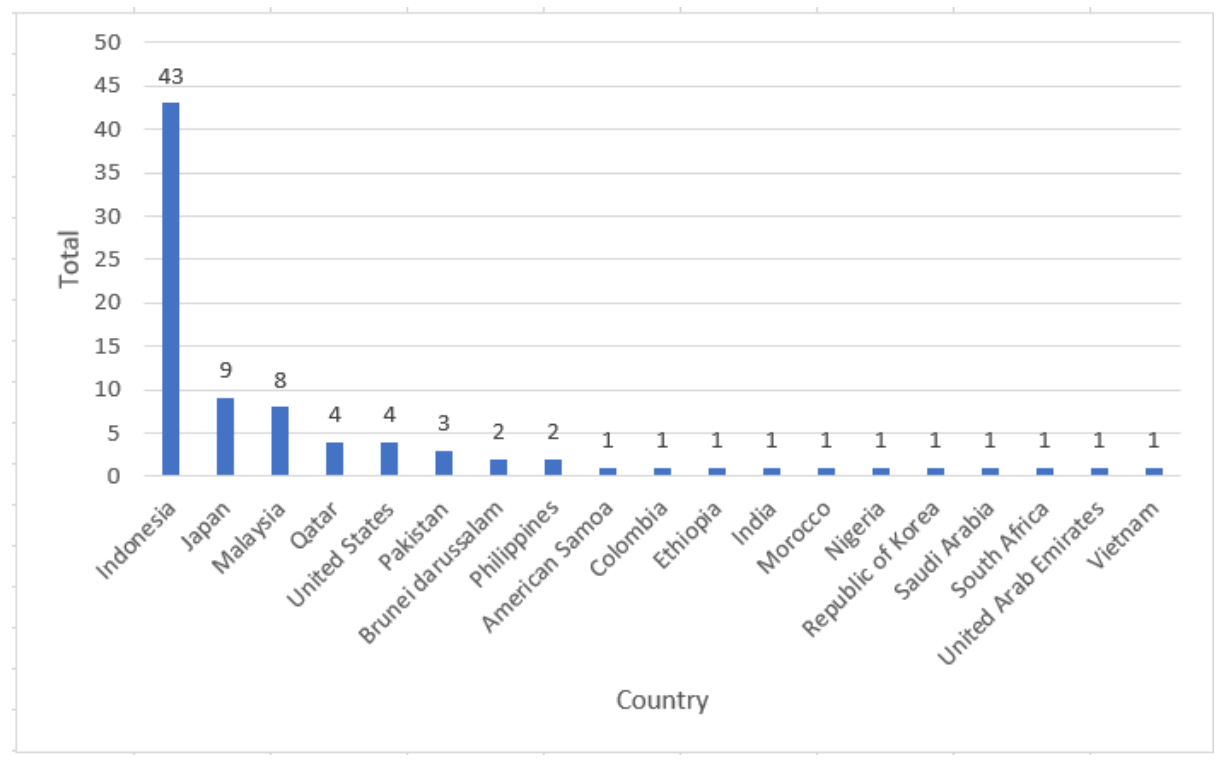

Figure 6 Total Countries Participating in Research Materials 


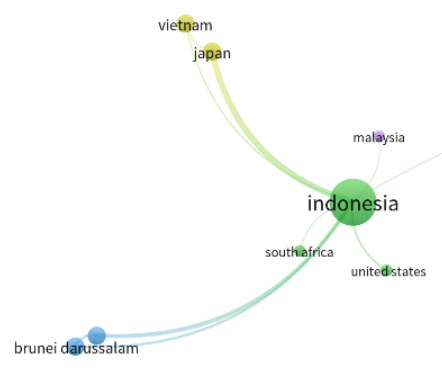

Figure 7 Network Visualization of Country Research.

\section{CONCLUSION}

This research was conducted to analyze the bibliometric articles about the material. In this study, the materials were divided into two categories, namely chemistry materials and educational materials. The search process uses the keyword "material" which is based on a topic area with titles, keywords, and abstracts. After the search process was carried out, 60 relevant articles were obtained. After that, the mapping process is carried out using VOSviewer. The search results found 60 relevant articles. Based on the results of analysis and mapping with VOSviewer, it was found that material research with term study was the most studied in the 2016-2021 range. Meanwhile, in the field of material chemistry, the term acid is the most studied. We also analyzed the countries involved in the process of publishing articles on material from seven selected journals. Indonesia contributed by donating 43 articles. In writing articles, Indonesia cooperates with 8 other countries, namely the United States, Malaysia, South Africa, Japan, Vietnam, and Qatar. The biometric approach is used in identifying key themes in each research that has been done so far and is useful for determining novelty in conducting further research. 


\section{REFERENCES}

Al Abbad, E. and Alakhras, F. 2020. Removal of dye acid red 1 from aqueous solutions using chitosan-iso-vanillin sorbent material. Indonesian Journal of Science and Technology. 5(3): 352-365.

Al Husaeni, D.F. and Nandiyanto, A.B.D. 2022. Bibliometric using Vosviewer with Publish or Perish (using google scholar data): From step-by-step processing for users to the practical examples in the analysis of digital learning articles in pre and post Covid-19 pandemic. ASEAN Journal of Science and Engineering. 2(1): 19-46.

Amri, S.M. and Pagarsukma, M.A. (2021). Airport development planning (case study: mozes kilangin international airport). Indonesian Journal of Multidiciplinary Research. 1(1): 63-68.

Asmara, Y.P., and Kurniawan, T. 2018. Corrosion prediction for corrosion rate of carbon steel in oil and gas environment: A review. Indonesian Journal of Science and Technology. 3(1); 64-74.

Awan, M.M.S., Soroushian, P., Ali, A., and Awan, M.Y.S. 2017a. High-performance cementitious matrix using carbon nanofibers. Indonesian Journal of Science and Technology. 2(1); 57-75.

Awan, M.M.S., Soroushian, P., Ali, A., and Awan, M.Y.S. 2017b. Use of carbon nanofibers in cementitious mortar. Indonesian Journal of Science and Technology. 2(2); 134151.

Awan, M.S., Ali, A., Perviz, S., and Awan, Y.S. 2019. Carbon nano fibre reinforcements in concrete. Indonesian Journal of Science and Technology. 4(1); 1-16.

Bhullar, L.K., and Putra, Z.A. 2017. Process design and modelling of the production of butyl cellosolve acetate and eo-3 phosphate ester. Indonesian Journal of Science and Technology. 2(2); 166-182. 
Bilad, M.R. 2017. Module-scale simulation of forward osmosis module-part B: Modified Spiral-Wound. Indonesian Journal of Science and Technology 2(2); 211-220.

Budiman, B.A., Sambegoro, P.L., Rahardian, S., Ilhamsyah, R., Firmansyah, R., Juangsa, F.B. and Aziz, M. 2020. Prediction of the remaining service lifetime of inflatable rubber dam with deep hole damage. Indonesian Journal of Science and Technology. 5(3); 366-381.

Castiblanco, P.A., Ramirez, J.L. and Rubiano, A. 2021. Smart materials and their application in robotic hand systems: A state of the art. Indonesian Journal of Science and Technology. 6(2); 401-426.

Elia, S.H., Maharani, B.S., Yustia, I., Girsang, G.C.S., Nandiyanto, A.B.D. and Kurniawan, T. 2021. Techno-economic evaluation of hyaluronic acid production through extraction method using yellowfin tuna eyeball. ASEAN Journal of Science and Engineering. 1(3); 161-170.

Errich, A., Azzaoui, K., Mejdoubi, E., Hammouti, B., Abidi, N., Akartasse, N., Benidire, L., Hajjaji, S. EL., Sabbahi, R. and Lamhamdi, A. 2021. Toxic heavy metals removal using a hydroxyapatite and hydroxyethyl cellulose modified with a new Gum Arabic. Indonesian Journal of Science and Technology 6(1); 41-64.

Fitriyana, N.I., Nishi, K. and Sugahara, T. 2021. Hypocholesterolemic activity of kedawung (Parkia roxburghii). Indonesian Journal of Science and Technology. 6(2); 353-360.

Hamidah, I., Sriyono, S. and Hudha, M.N. 2020. A Bibliometric analysis of Covid-19 research using VOSviewer. Indonesian Journal of Science and Technology. 5(2); 209216. 
Haristiani, N., and Rifa'i, M.M. 2020. Combining chatbot and social media: Enhancing personal learning environment (PLE) in language learning. Indonesian Journal of Science and Technology. 5(3); 487-506.

Kumalasari, I., Napiah, M. and Sutanto, M.H. 2018. A review on phase change materials incorporation in asphalt pavement. Indonesian Journal of Science and Technology. 3(2); 171-179.

Kurniawan, B., Kurnia, Y., Husna, I., Rahmat, A., Umam, R. and Andriana, B.B. 2020. Utilization of stem bark and leaves of kluwih (Artocarpus Altilis Park) as an antimosquito repellent: a case study of total mosquito mortality (Anopheles Sp). Indonesian Journal of Science and Technology. 5(3); 421-439.

Kurniawan, T., Fauzi, F.A.B. and Asmara, Y.P. 2016. High-temperature oxidation of Fe-Cr steels in steam condition-A review. Indonesian Journal of Science and Technology. 1(1); 107-114.

Maryanti, R. 2021a. Developing the creativity of elementary school students in Cimahi, Indonesia through online learning media during the covid-19 pandemic. Indonesian Journal of Teaching in Science. 1(1); 53-62.

Maulida, R., Daffa, M.N., Nadhira, S.F., Hotimah, A.P., Anggraeni, S. and Nandiyanto, A.B.D. 2021. Teaching concept of bio-battery material: Use of sweet potato peels and lime juice solution. Indonesian Journal of Teaching in Science. 1(1); 13-16.

Mukti, R.N., Salsabilla, A., Muamar, A.S., Prima, E.C., and Hana, M.N. 2021. Biogas effectiveness test from household waste (vegetable waste) with cow dung starter and EM4. Indonesian Journal of Multidiciplinary Research. 1(1); 73-78.

Nandiyanto, A.B.D. 2019. Nano metal-organic framework particles (ie MIL-100 (Fe), HKUST-1 (Cu), Cu-TPA, and MOF-5 (Zn)) using a solvothermal process. Indonesian Journal of Science and Technology. 4(2); 220-228. 
Nandiyanto, A.B.D., Andika, R., Aziz, M. and Riza, L S. 2018. Working volume and milling time on the product size/morphology, product yield, and electricity consumption in the ball-milling process of organic material. Indonesian Journal of Science and Technology. 3(2); 82-94.

Nandiyanto, A.B.D., Biddinika, M.K. and Triawan, F. 2020. How bibliographic dataset portrays decreasing number of scientific publication from Indonesia. Indonesian Journal of Science and Technology. 5(1); 154-175.

Nandiyanto, A.B.D., Oktiani, R., and Ragadhita, R. 2019. How to read and interpret FTIR spectroscope of organic material. Indonesian Journal of Science and Technology. 4(1); $97-118$.

Nandiyanto, A.B.D., Sofiani, D., Permatasari, N., Sucahya, T.N., Wiryani, A.S., Purnamasari, A., Rulis, A. and Prima, E. C. 2016. Photodecomposition profile of organic material during the partial solar eclipse of 9 march 2016 and its correlation with organic material concentration and photocatalyst amount. Indonesian Journal of Science and Technology. 1(2); 132-155.

Obielodan, O.O., Onojah, A.O., Iyiola, O.B., Onojah, A.A., and Taiwo, S.A. 2021. the design, construction, and expert appraisal of A 220v inverter. Indonesian Journal of Multidiciplinary Research. 2(1); 97-104.

Permatasari, N., Sucahya, T.N., and Nandiyanto, A.B.D. 2016. Agricultural wastes as a source of silica material. Indonesian Journal of Science and Technology. 1(1); 82-106.

Priyand, E.R.P., Sukmafitri, A., Mudzakir, A., Nandiyanto, A.B.D., Nugraha, W.C. and Ramdhani, W. 2020. Zinc oxide nanoparticles for enhancing students' view of the nature of science and technology. Indonesian Journal of Science and Technology. 5(1); $1-10$. 
Puta, Z.A. 2018. Lignocellulosic biomass pretreatment for birefinery: A review. Indonesian Journal of Science and Technology. 3(1); 75-81.

Saripudin, S., Rohendi, D. and Abdullah, A. G. 2020. Developing information technology in opencourseware: From movements to opportunities in Asia. Indonesian Journal of Science and Technology. 5(3); 308-320.

Setiyo, M., Yuvenda, D. and Samue, O.D. 2021. The Concise latest report on the advantages and disadvantages of pure biodiesel (B100) on engine performance: Literature review and bibliometric analysis. Indonesian Journal of Science and Technology. 6(3); 469490.

Sumarji, S., Ridha, F., Dwilaksana, D., Syuhri, A. and Raihaan, R. 2019. The effect of particle dispersion due to mixing speed on spent coffee ground composites. Indonesian Journal of Science and Technology. 4(2); 188-195.

Swamy, A. and Zebenay, T.A. 2020. An elephant foot analogy: Design and development of landing gear. ASEAN Journal of Science and Engineering. 1(2); 145-152.

Valensia, V., Sadiyyah, F.H., Hibatulloh, M.R., Setiadi, D.P., Nandiyanto, A.B.D. and Anggraeni, S. 2021. The effect of comparison of soybeans and coconut water on biobatterkectrical power. Indonesian Journal of Multidiciplinary Research. 1(1); 49-54. 